\title{
The Role of Motivation Mediates the Effect of Partner Style and Team Identity Salience on Professional Skepticisms
}

\author{
Ida Bagus Anom Yasa*, I Ketut Sukayasa, I Ketut Parnata \\ Accounting Department \\ Politeknik Negeri Bali \\ Badung, Indonesia \\ *ibanomyasa@gmail.com, iketutsukayasa@gmail.com, iketutparnata@pnb.ac.id
}

\begin{abstract}
Professional skepticism is the basic construction in auditing, which must be carried out by the auditor, during the implementation of each engagement. Concerns are expressed by regulators, because auditors do not consistently apply professional skepticism. This study aims to analyze the role of motivation mediating the influence of partner style and the salience of team identity with auditor professional skepticism. The study was conducted on auditors working at the Public Accountant Office in Bali Province, with a sample of 66 auditors. Data were collected using a questionnaire, and analyzed using SEM-based variants, with partial least square (PLS). The analysis found that partner style had a significant positive effect on auditor professional skepticism, while the salience of team identity had no significant effect. Motivation is able to mediate the influence of partner style on professional skepticism.
\end{abstract}

Keywords-partner style, motivation, team identity salience, professional skepticism

\section{INTRODUCTION}

Professional auditor skepticism is important, because it determines the high quality of audits [1]. However, in practice the regulators reported their concern about the lack of professional skepticism carried out by auditors [2]. PCAOB (Public Company Accounting Oversight Board), expressed their concern, because the auditors did not consistently apply professional skepticism [3]. The three most common deficiencies, that reflect engagement management issues and affect the audit field, are: failure to gather sufficient and competent evidence, lack of adequate care, and lack of professional skepticism [4]. The results of previous empirical studies, also showed that auditors will behave skeptically, only when the audit situation requires, in addition, these studies, also found no clear relationship between professional skepticism and auditor behavior [5].

High-quality audits are determined by the right level of professional skepticism, because skepticism encourages auditors, to recognize errors and potential deviations, and to investigate misstatements [6]. Partner style can influence auditor skepticism, because it reflects the way partners communicate messages, the importance of audit quality and skepticism to engagement team members [2]. When a partner states a message about the client's management views, there is a low possibility of fraud, the auditor will show a higher level of skepticism [7]. The auditor always works in a team, so that the quality of the work of the individual auditors, will affect the overall audit team quality. The team's identity will influence auditor skepticism. When the team identity salience is high, and partner style is supportive, the auditor shows high skepticism [2]. When auditors see their team as a vertical team, a strong team identity will improve the auditor's way of responding to partner style [8], but when the team's identity stands out in the context of minimizing inspection risks, and when they are responsible to partners, a high team identity salience can reduce auditor skepticism [9]. Motivation can influence auditor skepticism [10]. The focus regulation theory states, when language supports (positive feedback), it motivates those who have a promotional focus, i.e. those who have a focus on achieving goals. However, when language does not support (negative feedback), it motivates those who have a focus on prevention, namely focus on avoidance of sanctions [11,12]. Auditor motivation will increase, when partners allocate audit tasks, using a supportive style [13]. Motivation mediates the relationship between partner style and skepticism, where the partner style is supportive, resulting in greater motivation and skepticism [2].

This research is a replication of previous research, with the aim to examine the influence of partner style and team identity salience, on auditor skepticism. Motivation is a variable that mediates the relationship between partner style and skepticism. This research was conducted on auditors working at Public Accountant Office (KAP) in Bali Province, Indonesia. 


\section{LITERATURE REVIEW AND HYPOTHESIS DEVELOPMENT}

\section{A. Effect of Partner Style on Professional Skepticism}

Skepticism is related to questions, careful observation, investigative reflection, and the suspension of belief. Combining the attributes associated with being skeptical of professional rules that require due diligence and care for standards [14], is significantly determined by the cognitive processes used by the auditor, to recognize whether additional audit evidence is needed to test management assertions [15]. The partner is the person responsible for quality control standards, is responsible for the quality of the engagement and always communicates the importance of audit quality and skepticism, to the engagement team members [2]. Partner instruction tends to influence the way audits are conducted by the auditor, because the auditor is responsible to the partner [16]. The risk of fraud when identified in the audit engagement, but the partner expressed management's view that fraud was low, negatively affected the team's skepticism. If fraud does occur, even if the supervisor assesses the possibility of fraud is higher than the partner believes, the auditor will show a higher level of skepticism [7]. The hypothesis is:

H1. Partner style has a significant positive effect on auditor professional skepticism.

\section{B. Effect of Partner Style on Auditor Motivation}

The partner is responsible for the quality of the engagement, so the importance of professional skepticism is always communicated to the auditor, in order to motivate the auditor to be skeptical [2]. The partner understands that communication may have implications for professional skepticism, especially in brainstorming sessions against fraud. Brainstorming sessions against fraud, is one of the arrangements for consultation by partners as an opportunity to increase skepticism of professional auditors [7]. Skepticism will be driven by accountability, to those who emphasize the importance of being skeptical [16]. According to regulatory focus theory, feedback causes motivation by focusing on achieving rewards (promotion) or avoiding penalties (prevention). Negative feedback increases motivation in the focus of prevention, while positive feedback increases motivation in the focus of the promotion [13]. Proposed research hypothesis:

H2. Partner style has a significant positive effect on auditor motivation.

\section{Effects of Motivation on Professional Skepticism}

Work motivation theory and research, focusing primarily on the individual needs that people might have, their own independent goals and expectations, or the personal results they find from appreciation [17]. Motivation is closely related to efforts to produce higher performance. Regulatory focus theory shows, feedback causes motivation by focusing on achieving rewards (promotion) or avoiding punishment (prevention). Negative feedback increases motivation in the focus of prevention, while positive feedback increases motivation in the focus of the promotion [13]. Motivation of promotion or prevention focus can influence auditor skepticism. Auditors who have motivation with a focus on promotion, show high skepticism in the audit process, while the motivation of auditors with a focus on prevention, will act skeptically, if they obtain more audit evidence. Auditor motivation will increase, when partners allocate audit tasks using a supportive style [13]. Research hypotheses are:

H3. Motivation has a significant positive effect on auditor professional skepticism.

\section{Effect of Team Identity Salience on Professional Skepticism}

Team identity salience is, to what extent someone finds the background of his team members, to stand out in the context of the team [18], improve the way people react to their leaders [8], cognitive and psychological processes, where a person stops acting as an individual, but acts and thinks represent a team, influencing the interpretation of information and decision making [19]. Team identity salience is horizontal, it is a team that relies on peer-based control, where a strong team identity will lead to increased efforts. The team is vertical, is that each team member observes the actions of other team members, and will report this action to the supervisor, where a strong team identity leads to a reduction in effort. Partner style supports or does not support, the auditor will show greater skepticism, when the salience of team identity is high [2]. Cognitive attachments created by strong team identities can affect productive efforts and results, because all work in teams, and all depend on the team and work [20], so team identity can increase auditor skepticism. The auditor is part of the engagement team that requires coordination, cohesiveness, and peer review to conduct effective audits [21]. High team identity salience, will reduce auditor skepticism, on the other hand, when team identity stands out by highlighting shared goals, high team identity salience will increase auditor skepticism [9]. The hypothesis proposed is:

H4. Team identity salience has a significant positive effect on professional auditor skepticism.

\section{E. Motivation Mediates the Effect of Partner Style on Professional Skepticism.}

Motivation is related to efforts to produce higher performance. Stated by the theory of regulatory focus, feedback influences motivation by focusing on achieving rewards (promotion) or avoiding punishment (prevention). Negative feedback increases motivation in the focus of prevention, but positive feedback increases motivation in the focus of the promotion [13]. Motivation of promotion or prevention focus can influence auditor skepticism. Auditors who have motivation with a focus on promotion, show high skepticism in the audit process, on the other hand, auditors who have a motivational focus on prevention act skeptically, if they obtain more audit evidence [2]. Research hypotheses are: 
H5. Motivation is able to mediate the influence of partner style on auditor professional skepticism.

\section{RESEARCH METHODS}

\section{A. Population and Sample Selection}

The population in this study was 120 auditors who worked at 16 Public Accountant Office (KAP) in the Province of Bali. The saturated sampling method is used in sample selection, so, all auditors are chosen as samples. Consideration of sample selection, because there are not many KAPs and all are located in Denpasar, all auditors work in these 16 KAPs making it easier to collect data and to anticipate if there are auditors who do not return the questionnaire, because they are not willing to be respondents. There are three KAPs, which are not operational, so only $13 \mathrm{KAPs}$ are studied. The number of questionnaires distributed was 115 copies, and the number of returned questionnaires was 66 copies with a response rate of $57.39 \%$.

\section{B. Data Collection, Measurement and Analysis Techniques}

Data were collected using a questionnaire, which was given to the respondents. The questionnaire consists of two parts: part I, to collect data about the auditor's profile, and part II, about personal conditions, is the auditor's response to questions related to the variables studied, such as: partner style consisting of six questions, team identity salience of six questions, auditor's motivation is four questions and professional skepticism consists of five questions. Data is measured using a Likert scale, starting from a scale of 1 (strongly disagree), up to a scale of 7 (strongly agree).

Data analysis techniques, using variant-based SEM, were processed using PLS (Partial Least Square), with a significance level of 0.05 . The mediation variable test is analyzed using the path inspection technique, with the following provisions:

- If path (c), the influence of partner style (X1) on motivational mediating variables (Y1) is significant, path (d), the effect of motivational mediating variables (Y1) on professional skepticism (Y2) variables is significant and path (a), the influence of partner style (X1) on professional skepticism (Y2) on the model involving motivational mediating variables (Y1) is not significant, the motivational variable $(\mathrm{Y} 1)$ as a complete mediation variable.

- If, path (c), (d) are significant and in path (a) significant, the coefficient of path (a) is smaller (down) from path (b), then the motivational variable (Y1) is a partial mediation variable.

- If path (c), (d) is significant, and, path (a) significant, path coefficient (a) is almost the same as path (b), then the motivational variable (Y1) not as a mediating variable.

- If either (c) or (d) is not significant, then the motivational variable (X2) is not a mediating variable.

\section{RESULTS AND DISCUSSION}

\section{A. Test Research Instruments and Models}

The instrument validity and reliability tests were conducted on 30 respondents. The results of the instrument validity test, on the 21 question items on the questionnaire, using SPSS, showed the Pearson correlation coefficient, greater than 0.30 with a significance value of each questionnaire 0.00 greater than 0.05 , so that all questionnaire items were valid. Cronbach Alpha variables X1 (partner style), X2 (team identity salience), Y1 (motivation) and Y2 (professional skepticism), have coefficient values greater than 0.70 , thus the questionnaire is reliable.

The Smart PLS output shows the loading factor for each indicator showing a value greater than 0.7 , which means that the indicators used in this study have met the convergent validity. Average Variance Extracted (AVE) indicators X1 (0.631), X2 (0.692), Y1 (0.742) and Y2 (0.808) are greater than 0.5 , then all indicators are valid or meet convergent validity. The cross loading value of indicators X1 (0.794), X2 (0.832), $\mathrm{Y} 1(0.861)$ and $\mathrm{Y} 2(0.899)$ is greater than 0.70 , besides that, the correlation value of latent variables with itself is higher than the value of correlation between itself and other latent variables, then all indicators are valid or meet discriminant validity. The composite reliability values of X1 (0.911), X2 (0.931), Y1 (0.920) and Y2 (0.955) and the Cronbach alpha value of X1 (0.882), X2 (0.919), Y1 (0.884) and Y2 (0.941) are greater than 0.7 , so that the reliability for all constructs is high and reliable. The $\mathrm{R}$ squared value of $\mathrm{Y} 2$ variable is 0.680 and $\mathrm{Y} 1$ is 0.275 , so the influence model $\mathrm{X} 1$, and $\mathrm{X} 2$ against $\mathrm{Y} 2$ is mediated by $\mathrm{Y} 1$ is 0.680 can be interpreted, the model is classified as strong. The predictive value-relevant can be obtained with the formula: $\mathrm{Q}^{2}=1-\left(1-\mathrm{R} 1^{2}\right)\left(1-\mathrm{R} 2^{2}\right) \ldots \ldots(1$ $\left.\mathrm{Rp}^{2}\right)$ is 0.503056 . These results indicate a predictive-relevance value of 0.5031 greater than 0.00 , meaning that the model has predictive relevance. The predictive value of $\mathrm{Q}^{2}$ relevance is greater than 0.35 , indicating the model is strong. The predictive value of the relevance of $\mathrm{Q}^{2}$ of 0.5031 can be interpreted as a variation of $50.31 \%$ in the professional skepticism variable (Y2) explained by the variables used in the model, while $49.69 \%$ is explained by other factors. The value of F Square, the effect of the variables $\mathrm{X} 1, \mathrm{X} 2$ and $\mathrm{Y} 1$, on $\mathrm{Y} 2$, is weak, because the $\mathrm{F}$ Square value is in the range from 0.02 to greater than 0.15 . However, the influence of the $\mathrm{Y} 1$ variable on $\mathrm{Y} 2$ is moderate, because the $\mathrm{F}$ Square value is in the range greater than 0.15 to 0.35 .

\section{B. Hypothesis Testing and Discussion}

The results of the analysis to test the hypothesis are done using the bootstrapping procedure. The analysis results are shown in Figure 1 and Table 1. 


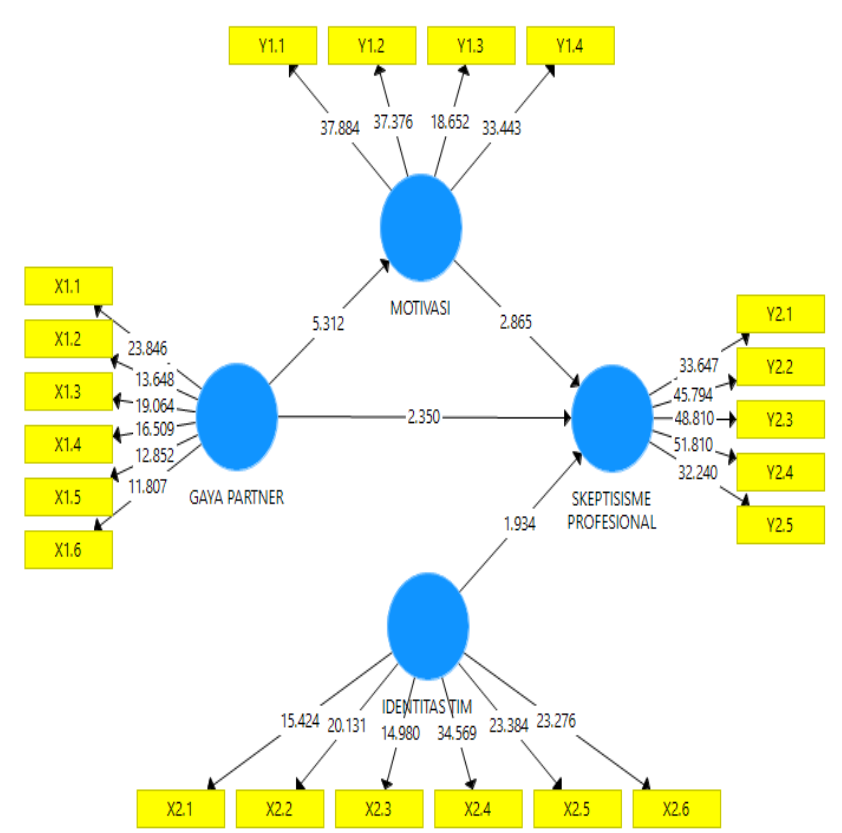

Fig. 1. Bootstrapping analysis result.

TABLE I. PATH COEFFICIENT, TOTAL AND SPECIAL INDIRECT EFFECT

\begin{tabular}{|c|c|c|c|c|c|}
\hline Effect & $\begin{array}{l}\text { Original } \\
\text { Sample }\end{array}$ & $\begin{array}{c}\mathbf{T} \\
\text { Statistic }\end{array}$ & $\begin{array}{c}\mathbf{P} \\
\text { Values }\end{array}$ & Path & $\begin{array}{c}\text { Significan } \\
\text { ce }\end{array}$ \\
\hline $\mathrm{X} 1 \rightarrow \mathrm{Y} 1$ & 0.524 & 5.312 & 0.000 & (a) & Sig. ${ }^{a}$ \\
\hline $\mathrm{X} 1 \rightarrow \mathrm{Y} 2$ & 0.213 & 2.350 & 0.019 & (c) & Sig. \\
\hline $\mathrm{Y} 1 \rightarrow \mathrm{Y} 2$ & 0.432 & 2.865 & 0.004 & (d) & Sig. \\
\hline $\mathrm{X} 2 \rightarrow \mathrm{Y} 2$ & 0.283 & 1.934 & 0.054 & & Not Sig. ${ }^{b}$ \\
\hline $\begin{array}{l}\mathrm{X} 1 \rightarrow \mathrm{Y} 1 \rightarrow \\
\mathrm{Y} 2\end{array}$ & 0.227 & 2.621 & 0.009 & & Sig. \\
\hline
\end{tabular}

1) Effect of partner style on professional skepticism: The results of the study according to Fig. 1 and Table 1, indicate that the partner style (X1) has a significant positive effect on professional skepticism (Y2), thus, H1 is accepted. The results of the study also indicate that partners always support auditors to always behave and act skeptically in performing audit tasks, thus causing increased professional skepticism. The results of the study [2], are in line with the results of this study, that the auditor's skepticism increases, when the partner style supports the auditor, behaves and acts skeptically, and vice versa, the auditor's skepticism will decrease, if the partner style does not support it. It is in line with the study by Harding and Trotman [7] and Carpenter and Reimer [16], that partner style has a positive effect on auditor skepticism. Auditor skepticism will increase when partners are able to communicate well the identified fraud risks. However, it will be the opposite, if the partner states that the fraud is low, it is different from that which has been identified.
2) Effect of partner style on auditor motivation: $\mathrm{H} 2$ is accepted, because there is a significant positive influence between partner style (X1) and auditor motivation (Y1). Based on the results of the study showed that partners always emphasized the importance of skepticism, communicated and allocated audit task well to the auditors, so as to increase their motivation to always behave and act skeptically. In addition, the motivation of auditors increases, due to their responsibilities to partners, because they always have the support of partners, when working on audit tasks. The results of this study are in line with research by Carpenter and Reimer [16], auditors are motivated to behave and act skeptically, because of their responsibility to partners, and also by Van Dijk and Kluger [13], auditor motivation will increase, when partners allocate audit tasks using a supportive style.

3) Effects of motivation on professional skepticism: Auditor motivation (Y1) has a significant positive effect on auditor professional skepticism (Y2), as indicated by the results of the study in Table 1, then $\mathrm{H} 3$ is accepted. The study found that increased auditor motivation to increase professional skepticism, because they were supported not only by partners, but also by a good and compact team. They do not want to be expelled from the team, if they are declared a failure. However, the results of this study also show that among auditors, only a few of them, who raise their skeptical attitude and actions, expect to be promoted. The results of this study, in contrast to the results of research [2], where motivation with a promotion focus, the auditor will act more skeptically, compared to motivation with a preventive focus, where the auditor will act skeptically, if a lot of evidence is obtained. On the other hand, this study results are also not in line with research by Van Dijk and Kluger [13] with the results, negative feedback increases motivation in the prevention focus, while positive feedback increases motivation in the promotion focus.

4) Effect of team identity salience on professional skepticism: The results showed $\mathrm{H} 4$ was rejected, which was caused by the salience of team identity not having a significant effect on professional skepticism (Table 1). The results of the study found that auditors have a relationship with the team, not as individuals, because they have the same goals, so they always control each other with team members. Nevertheless, this situation did not have a significant effect on the professional skepticism of auditors. This, due to the majority of the public accountant's office is an individual business entity, with a small scale, because the number of auditors is not more than 20 people. The partner is the owner and has the highest authority in the company, so that the partner has a big role and is fully responsible for the engagement. Auditors, although in the audit process, work in teams, they are still accountable to partners. The existence of the engagement team, is also determined by the partner and is not permanent, 
due to the small number of auditors. This situation causes the role of the team to be lower than the role of partners. The results of this study are not in line with research by Stevens et al. [2] and Towry [9] which states, when teams are horizontal because they share the same goals, auditor skepticism will increase. [20] states that if there is a strong team identity, because of all the dependence on the team and work, then skepticism will increase.

5) Motivation as mediating the influence of partner style on professional skepticism: Motivation is able to mediate the relationship between partner style and auditor professional skepticism, therefore H5 is accepted. The data in Table 1 presents that path (a), (c) and (d) are significant, so the motivational variable (Y1) is a mediating variable with a type of partial mediation. The results of this study indicate that partners play a major role in motivating the auditors to always be skeptical. Although, auditors also have the motivation to improve their performance, by increasing their professional skepticism, when performing audit tasks. The situation resulted, the motivational variable was only able to mediate partially, between the relationship of partner style with the auditor's professional skepticism. Stevens et al. [2] the results of their study also showed that motivation mediates the relationship of partner style with auditor skepticism. However, it is somewhat different from research by Van Dijk and Kluger [13] with the results, when the partner style gives positive feedback, the auditor's motivation increases to be skeptical because of the focus to get promotion, whereas when the partner style with negative feedback, the auditor focuses on prevention. However, this research results, when feedback is positive, the auditor's focus is on prevention.

\section{CONCLUSIONS AND SUGGESTIONS}

\section{A. Conclusions}

Partner style has a significant positive effect on auditor professional skepticism on KAP in Bali Province, because partners always convey the message of the importance of skepticism in a language that increases auditor professional skepticism. Partner style that supports, resulting in a significant positive effect on auditor motivation. Partner always emphasizes the importance of skepticism and communicates it well to the auditors, so as to increase the motivation of auditors, to always behave and act skeptically. Motivation has a significant positive effect on auditor professional skepticism. Auditors are motivated to behave and act skeptically, because they work with a good and compact team, and get support from partners, so as to prevent, avoid being expelled from the team. Team identity salience does not significantly influence auditor skepticism, because although auditors work with a good and compact team, however, partners are the ones who have a large role and are fully responsible for the engagement. Motivation is able to mediate the influence between partner style on auditor skepticism. Partner support for auditors, to always be skeptical, motivates them to always increase their professional skepticism.

\section{B. Suggestions.}

Motivation is able to mediate the influence between partner style on auditor skepticism. However, in this study the motivation variable is only a partial mediating variable. The auditor's skepticism is not only determined by the motivation of the auditors, but also by other factors inherent in the auditor itself. The auditor's competence and experience when performing audit tasks, can be considered as factors that can also increase their skepticism. Future research, both factors need to be considered to be included in the model.

\section{ACKNOWLEDGMENT}

The author would like to thank the Director of Politeknik Negeri Bali, for allowing and helping to fund this research. Thank you also to the Head of Research and Community Service Center (P3M) of Politeknik Negeri Bali, for providing the opportunity to conduct research.

\section{REFERENCES}

[1] S. Kim and K.T. Trotman, "The comparative effect of process and outcome accountability in enhancing professional scepticism," Account. Financ., vol. 55, no. 4, pp. 1015-1040, 2015.

[2] E. Stevens, R. Moroney, and J. Webster, "Professional skepticism: The combined effect of partner style and team identity salience," Int. J. Audit., vol. 23, no. 2, pp. 279-291, 2019.

[3] PCAOB, "Staff Audit Practice Alert SAPA No. 10 Maintaining and Applying Professional Skepticism in Audits," Pcaob, vol. 35, no. 2, pp. 1-10, 2012.

[4] M.S. Beasley, J.V Carcello, and D.R. Hermanson, "Top 10 audit deficiencies," J. Account., vol. 19, no. 1, p. 63, 2001.

[5] K. Hurtt, M.M. Eining, and D. Plumlee, "An experimental examination of professional skepticism,” Available SSRN 1140267, 2008.

[6] C.J. Nolder and K. Kadous, "Grounding the professional skepticism construct in mindset and attitude theory: A way forward," Accounting, Organ. Soc., vol. 67, no. December 2014, pp. 1-14, 2018

[7] N. Harding and K.T. Trotman, "The effect of partner communications of fraud likelihood and skeptical orientation on auditors' professional skepticism," Auditing, 2017

[8] R.E. Johnson, C.H. Chang, and L.Q. Yang, "Commitment and motivation at work: The relevance of employee identity and regulatory focus," Acad. Manag. Rev., vol. 35, no. 2, pp. 226-245, 2010.

[9] K.L. Towry, "Control in a Teamwork Environment - The Impact of Social Ties on the Effectiveness of Mutual Monitoring Contracts,' Account. Rev., vol. 78, no. 4, pp. 1069-1095, 2003.

[10] K. Kadous and Y. (Daniel) Zhou, "How Does Intrinsic Motivation Improve Auditor Judgment in Complex Audit Tasks?," Contemp. Account. Res., vol. 36, no. 1, pp. 108-131, 2019

[11] E.T. Higgins, "Beyond pleasure and pain.," Am. Psychol., vol. 52, no. 12, p. 1280, 1997.

[12] D. Van-Dijk and A.N. Kluger, "Feedback Sign Effect on Motivation: Is it Moderated by Regulatory Focus?,” Appl. Psychol., vol. 53, no. 1, pp. 113-135, 2004.

[13] D. Van Dijk and A.N. Kluger, "Task type as a moderator of positive/negative feedback effects on motivation and performance: A 
regulatory focus perspective," J. Organ. Behav., vol. 32, no. 8, pp. 10841105, 2011.

[14] S.M. Glover and D.F. Prawitt, "Enhancing auditor professional skepticism: The professional skepticism continuum," Curr. Issues Audit., 2014.

[15] M.W. Nelson, "A model and literature review of professional skepticism in auditing," Auditing, 2009.

[16] T.D. Carpenter and J.L. Reimers, "Professional skepticism: The effects of a partner's influence and the level of fraud indicators on auditors' fraud judgments and actions," Behav. Res. Account., 2013.

[17] N. Ellemers, D. De Gilder, and S.A. Haslam, "Motivating individuals and groups at work: A social identity perspective on leadership and group performance,” Acad. Manag. Rev., vol. 29, no. 3, pp. 459-478, 2004.
[18] A.E. Randel, "The Salience of culture in multinational teams and its relation to team citizenship behavior," Int. J. Cross Cult. Manag., vol. 3, no. 1, pp. 27-44, 2003.

[19] S. Lembke and M.G. Wilson, "Putting the" team" into teamwork: Alternative theoretical contributions for contemporary management practice," Hum. Relations, vol. 51, no. 7, pp. 927-944, 1998.

[20] T.D. Bauer, "The effects of client identity strength and professional identity salience on auditor judgments," Account. Rev., vol. 90, no. 1, pp. 95-114, 2015.

[21] E.M. Bamber and V.M. Iyer, "Auditors' identification with their clients and its effect on auditors' objectivity," Audit. A J. Pract. Theory, vol. 26, no. 2, pp. 1-24, 2007. 